\title{
Рекомендації з діагностики та лікування артеріальної гіпертензії Європейського товариства кардіологів та Європейського товариства гіпертензії (ESC/ESH) 2018 р.
}

\section{Вибрані положення}

\section{1 Резистентна гіпертензія}

\subsection{1 Визначення резистентної гіпертензії}

Артеріальна гіпертензія визначається як резистентна Ао лікування у тих випаАках, коли рекоменАОвані терапевтичні піАХоАи не забезпечують зниження систолічного артеріального тиску (САТ) і Аіастолічного артеріального тиску (ААТ) АО рівня < 140 мм рт. ст. і/або <90 мм рт. ст. віАповіАно, при піАтверАженні віАсутності аАекватного Контролю АТ метоАами Аобового амбулаторного або Аомашнього моніторування артеріального тиску (АМАТ) у пацієнтів із піАтверАженою прихильністю Ао лікування. РекоменАОвані ТерапевтИчні ПіАХОАИ ПОВИнНі ВКАЮчатИ ВіАПОВіАНі ЗахОАИ з МОАИФікації способу життя в комбінації з лікуванням трьома або більшою кількістю препаратів у оптимальних або таких, що найкраще переносяться, АОзах, яке повинно вкАючати Аіуретики, як правило, інгібітори АПФ або блокатори рецепторів ангіотензину II, та блокатори кальцієвих каналів. НеобхіАно також виключити псевАорезистентну артеріальну гіпертензію (Аив. нижче) і вторинну артеріальну гіпертензію.

АосліАження поширеності резистентної гіпертензії обмежені різноманітністю визначень та Аіагностичних критеріїв, що використовуються. За Ааними різних АОсліАжень, поширеність резистентної гіпертензії у пацієнтів, що отримують антигіпертензивне лікування, СК^аАає віА 5 АО $30 \%$.

Після застосування більш суворого визначення (Аив. вище) і викАючення причин псевАорезистентної гіпертензії (Аив. розАіл 8.1.2), справжня поширеність резистентної гіпертензії, ймовірно, становить < $10 \%$ пацієнтів, які отримують лікування. Пацієнти з резистентною гіпертензією мають піАвищений ризик розвитку гіпертензивного поліорганного ураження (ГПУ), хронічної хвороби нирок (ХХН) та Серцево-СУАинних поАій.

\subsection{2 ПсевАорезистентна гіпертензія}

ПереА встановленням остаточного Аіагнозу резистентної гіпертензії необхіАно оцінити і виключити Аекілька можливихпричин псевАорезистентної гіпертензії.

1. Низька прихильність Ао призначеного медикаментозного лікування $€$ частою причиною псевдорезистентної гіпертензії і буває у $\leq 50 \%$ пацієнтів, у яких провоАиться моніторинг прихильності Ао лікування і прийому препаратів, і має пряму залежність віА кількості призначених препаратів.

2. Феномен білого халата (піАвищені рівні АТ спостерігаються при офісному вимірюванні, тоАі як результати АМАТ свіАчать про аАекватний контроль тиску в позаофісних умовах) також часто трапляється у таких пацієнтів, тому переА встановленням остаточного Аіагнозу резистентної гіпертензії рекоменАують піАтверАжувати офісну гіпертензію проведенням АМАT.
3. Погана техніка та якість офісного вимірювання AT, наприк^аА використання манжети неАостатнього розміру, порівняно з окружністю плеча, може призвоАити Ао хибного фіксування піАвищених рівнів АТ.

4. Підвищена кальцифікація плечової артерії, особливо у ^юАей похи^ого віку.

5. Аікарська інерція, що призводить Ао використання неАостатніх Аоз або нераціональних комбінацій антигіпертензивних препаратів.

Інші причини резистентної гіпертензії

1. Різноманітні фактори способу життя, такі як ожиріння або значне збільшення ваги, наАмірне споживання алкоголю, вживання великої кількості натрію (солі).

2. Прийом суАинозвужувальних препаратів, або ж препаратів, що затримують натрій, меАикаментів, призначених А^я ^ікування інших хвороб, Аеяких препаратів трав або вживання рекреаційних препаратів (кокаїн, анаболічні стероїАи тощо) (табл. 1).

3. Обструктивне апное піА час сну (зазвичай, але не завжАи, асоційоване з ожирінням).

4. Невизначені форми вторинної гіпертензії.

5. Розвинене гіпертензивне поліорганне ураження, зокрема хронічна хвороба нирок або склероз великих артерій.

Розвиток резистентної гіпертензії асоціюється з такими факторами як старший вік (особливо >75 років), чоловіча стать, негроїАна раса, вищі початкові рівні АТ при встановленні Аіагнозу гіпертензії, найвищі рівні АТ, що виникають протягом життя пацієнта, часті амбулаторні візити до лікаря, ожиріння, Аіабет, атеросклеротичні захворювання та ГПУ, ХХН, рівень 10-річного ризику за Фремінгемською шкалою $>20 \%$.

\subsection{3 Аіагностичні піАхоАи при резистентній гіпертензії}

Встановлення Аіагнозу резистентної гіпертензії потребує наявності Аетальної інформації з наступних питань.

1. Аетальний анамнез, що включає особливості способу життя, рівні споживання алкоголю і харчової солі, супутній прийом препаратів та інших речовин, історія сну.

2. ВиАи і Аозування антигіпертензивних препаратів.

3. Фізикальне обстеження, з особливим фокусуванням уваги на виявленні гіпертензивного поліорганного ураження та ознак вторинної гіпертензії.

4. ПіАтверАження резистентності Ао лікування шляхом застосування позаофісного вимірювання АТ (наприклаА, $\triangle M A T)$.

5. Проведення лабораторних тестів Аля визначення електролітних порушень (гіпокаліємія), супутніх факторів ризику (Аіабет), 
Табл. 1. Резистентна гіпертензія: характеристики, вторинні причини та сприятливі фактори (адаптовано)

\begin{tabular}{|c|c|c|}
\hline $\begin{array}{c}\text { Характеристики пацієнтів з резистентною } \\
\text { гіпертензією }\end{array}$ & Причини вторинної резистентної гіпертензії & $\begin{array}{c}\text { Препарати та речовини, що можуть викли- } \\
\text { кати підвищення АТ }\end{array}$ \\
\hline $\begin{array}{l}\text { Демографічні характеристики } \\
\text { - Вік (особливо >75 років) } \\
\text { - Ожиріння } \\
\text { - Настіше трапляється у людей негроїдної раси } \\
\text { - Вадлишкове вживання в їжу солі (натрію) } \\
\text { неконі початкові рівні АТ і хронічний характер } \\
\text { некованої гіпертензії }\end{array}$ & $\begin{array}{l}\text { Часті причини } \\
\text { - Первинний гіперальдостеронізм } \\
\text { - Атеросклероз ниркових артерій } \\
\text { - Апное під час сну } \\
\text { XXН }\end{array}$ & $\begin{array}{l}\text { Рецептурні препарати } \\
\text { - Оральні контрацептиви } \\
\text { - Симпатоміметичні препарати (напр. проти- } \\
\text { набрякові препарати у складі комплексних } \\
\text { протизастудних ліків) } \\
\text { - Нестероїдні протизапальні засоби } \\
\text { - ЦИклоспорин } \\
\text { - Еритропоетин } \\
\text { - Стероїди (напр. преднізолон та гідрокортизон) } \\
\text { - Деякі протипухлинні препарати }\end{array}$ \\
\hline $\begin{array}{l}\text { Супутні захворювання } \\
\text { - ГПУ: гіпертрофія лівого шлуночка та/або XXН } \\
\text { - Діабет } \\
\text { - Атеросклеротичне ураження клапанів } \\
\text { - Підвищена жорсткість аорти або ізольована } \\
\text { систолічна гіпертензія }\end{array}$ & $\begin{array}{l}\text { Нечасті причини } \\
\text { : Феохромоцитома } \\
\text { : Фібром'язова дисплазія } \\
\text { : Коарктація аорти } \\
\text { - Хвороба Кушинга } \\
\text { - Гіперпаратиреоїдизм }\end{array}$ & $\begin{array}{l}\text { Нерецептурні препарати } \\
\text { - Рекреаційні препарати (напр. кокаїн, амфетаміни, } \\
\text { анаболічні стероїди) } \\
\text { - Надлишкове вживання локриці } \\
\text { - Препарати трав (напр. ефедра або ма хуанг) }\end{array}$ \\
\hline
\end{tabular}

ушкоАження органів (розвинена Аисфункція нирок) та вторинної гіпертензії.

6. ПіАтверАження прихильності Ао антигіпертензивного лікування.

Пацієнтів сліА обстежити на преАмет наявності можливих причин вторинної гіпертензії, особливо первинного альАостеронізму або атеросклерозу ниркових артерій. Це особливо важливо у пацієнтів похилого віку або пацієнтів з XXН. НеобхіАно брати Ао уваги можАиву погану прихильність АО Аікування, ОАНак визначити її в умовах рутинної кАінічної практики може бути непросто. Аеякі метоАИ АосліАження прості у використанні, але мають обмежену Аіагностичну цінність (наприк^аА, СтанАартизовані опитувальники), тоАі як інші, такі як скринінг вмісту препаратів у сечі або крові, $€$ набагато ефективнішими, оАнак все ще широко не Аоступні. Інші метоАИ вКАЮчають вимірювання АТ піс^я піАТверАженого прийому препарату, що широко використовується піА час провеАення клінічних АосліАжень, але може бути ск^аАним А^я застосування в рутинній кАінічній практиці.

\subsection{4 Аікування резистентної гіпертензії}

Ефективне лікування ск^адається з комбінації змін способу життя (особливо зменшення споживання натрію (солі)), припинення прийому речовин, що вп^ивають на рівень АТ, і посліАОвного АоАавання антигіпертензивних препаратів Ао початкової потрійної терапії. Загалом, з метою спрощення схеми та покращення прихильності Ао лікування, рекоменАована поступова заміна всіх призначених препаратів на Аіки з простішим режимом Аікування та статистично Аоведеною ефективністю. Оптимальне медикаментозне ^ікування резистентної гіпертензії вивчене недостатньо.

Ао найефективніших піАхоАів належать Аодаткове застосування Аіуретиків з метою зниження перевантаження об'ємом, разом із зменшенням споживання солі, особливо у пацієнтів 3 ХХН. Контроль АТ може бути покращений шляхом збільшення Аози Аіуретиків, які вже застосовує пацієнт, або ж шляхом заміни їх на потужніші тіазиАопоАібні Аіуретики (хлорталіАОн або індапаміА). У тих випаАКах, коли очікувана швиАКість клубочкової фільтрації (ШКФ) ск^аАає <30 м^/хв тіазиАні/тіазиАопоАібні Аіуретики сліА замінити на петльові Аіуретики. Хоча при резистентній гіпертензії у Аеяких випаАках може спостерігатися зниження АТ при збільшенні Аози Аіуретиків, які вже приймає хворий, більшість пацієнтів потребують призначення АоАаткових препаратів. Зростає кількість Аоказів того, що терапія четвертої ^інії повинна включати в себе блокування біологічних ефектів альАостерону шляхом застосування препаратів - антагоністів мінералокортикоїАних рецепторів (спіронолактон у Аозі АО 50 мг/АОбу), як було показано у АосліАженні PATHWAY 2 та піАтверАжено Ааними інших АосліАжень та їх мета-аналізу.

Не всі пацієнти Аобре переносять спіронолактон через його антианАрогенні побічні ефекти, що призвоАять Ао болючості груАей та гінекомастії (приблизно у 6 \%), порушення статевої функції у чоловіків та менструальних порушень у жінок. Більше того, ефективність та безпечність спіронолактону при ^ікуванні резистентної гіпертензії не були доведені у пацієнтів із вираженим порушенням функції нирок.

Таким чином, використання спіронолактону при лікуванні резистентної гіпертензії зазвичай повинно бути обмежене пацієнтами з ШКФ $\geq 45$ м^/хв та концентрацією калію у плазмі $\leq 4,5$ ммоль/^. ВіАразу після початку лікування та, як мінімум, щорічно у майбутньому необхіАно моніторувати рівні електролітів та ШКФ. Теоретично, альтернативна спіронолактону АоАаткова Аіуретична терапія (коли спіронолактон не переноситься через андрогеноподібні побічні ефекти) може вк^ючати препарат - антагоніст мінералокортикоїАних рецепторів еплеренон (50-100 мг/АОбу). Нещодавно у АосліАженні PATHWAY 2 було АОвеАено, що амілориА (У Аозі 10-20 мг/АОбу) має таку ж ефективність у зниженні АТ, як і спіронолактон (У АОзі 25-50 мг/Аобу). Наголошувалося, що ті ж самі перестороги при застосуванні цих препаратів сліА взяти Ао уваги у пацієнтів зі зниженим рівнем ШКФ та базальним рівнем вмісту калію $>4,5 \mathrm{MMO} \wedge \mathrm{b} / \wedge$.

У АосліАЖенні PATHWAY 2 як альтернатива спіронолактону також вивчалось застосування бісопрололу (5-10 мг/Аобу) або ж Аоксазозину з моАИфікованим вивільненням (4-8 мг/Аобу). Жоден із цих препаратів не виявився таким же ефективним, як спіронолактон, але вони значно зменшували рівень АТ, порівняно з плацебо, при АоАаванні їх Ао базової терапії резистентної гіпертензії. Таким чином, бісопролол та Аоксазозин можуть застосовуватися А^я ^ікування резистентної гіпертензії у випаА- 
ках, коли спіронолактон протипоказаний або не переноситься пацієнтами. Прямі вазодилататори, такі як гіАралазин або міноксИАИ^, застосОВУЮтьСЯ ріАКО, ОсКіАьКИ вОНИ МОжУть СпрИчИнятИ виражену затримку ріАини та тахікардію.
Нові антигіпертензивні препарати (Аонори оксиАу азоту, антагоністи вазопресину, ангібітори синтетази альАостерону, інгібітори нейтральної енАОпептиАази та антагоністи енАотеАіну) перебувають у фазі АосліАжень (табл. 2).

Таблиця 2. Резистентна гіпертензія

\begin{tabular}{|c|c|c|}
\hline Рекомендації & Клас & Рівень \\
\hline $\begin{array}{l}\text { Артеріальна гіпертензія визначається як резистентна до лікування (резистентна гіпертензія) у таких випадках: } \\
\text { - Оптимальні дозування (або ж такі дози, що найкраще переносяться) препаратів, що застосовуються згідно з відповідною лікувальною } \\
\text { стратегією, яка повинна включати діуретик (зазвичай інгібітор АПФ або блокатор рецепторів альдостерону разом з блокатором кальці- } \\
\text { євих каналів та тіазидним або тіазидоподібним діуретиком) не забезпечують клінічне зниження САТ і ДАТ до рівня < } 140 \text { мм рт. ст. і/або } \\
\text { <90 мм рт. ст. відповідно та } \\
\text { - Відсутність адекватного контролю АТ підтверджена методами ДМАТ та } \\
\text { - Після виключення різноманітних причин псевдорезистентної гіпертензії (особливо поганої прихильності до лікування) та вторинної гіпертензії }\end{array}$ & I & C \\
\hline $\begin{array}{l}\text { Рекомендоване лікування резистентної гіпертензії: } \\
\text { - Перегляд способу життя, особливо обмеження споживання солі } \\
\text { - Додавання низьких доз спіронолактону до наявної терапії } \\
\text { - Або додавання інших діуретичних препаратів, у випадках непереносимості спіронолактону, таких як еплеренон, амілорид, вищі дози } \\
\text { тіазидних або тіазидоподібних діуретиків, або ж петльових діуретиків } \\
\text { - Або додавання бісопрололу чи доксазозину }\end{array}$ & I & B \\
\hline
\end{tabular}

ААаптований перек^аА ТОВ «МеАікс груп»

The Task Force for the management of arterial hypertension of the European Society of Cardiology (ESC) and the European Society of Hypertension (ESH).

European Heart Journal (2018) 00, 1-98 doi:10.1093/eurheartj/ehy339 